\author{
M ykola Gomelya, Inna Trus and Tetyana Shabliy
}

\title{
APPLICATION OF ALUMINIUM COAGULANTS FOR THE REMOVAL OF SULPHATE FROM MINE WATER
}

\author{
National Technical University of Ukraine "Kyiv Polytechnic Institute" \\ Chemical Engineering Faculty, Department of Ecology and Plant Polymers Technology \\ 37, Peremogy Ave., 03056 Kyiv, Ukraine; inna.trus.m@gmail.com
}

Received: M arch 20, 2013 / Revised: M arch 25, 2013 / Accepted: June 07, 2013

(C) Gomelya M., Trus I., Shabliy T., 2014

\begin{abstract}
The results of treatment of solutions with high sulphates concentration and the high rate of water hardness are given. It is shown that significant reduction of secondary pollution by chlorides is achieved through integrated use of aluminium hydroxchloride and sodium aluminate coagulants. It was found that the efficiency of water purification from sulphates and water softening can be increased with the carbon dioxide processing.
\end{abstract}

Keywords: nanofiltration water treatment, sulphates, water hardness, softening, aluminium coagulant, lime, mines water.

\section{Introduction}

Existing technologies of sewage purification can effectively remove organic and insoluble inorganic impurities, but these technologies have little effect on the level of mineralization in sewage waters. In fact, application of these technologies can sometimes even raise the concentration of salts in the water [1]. As a result, many natural water reservoirs in the industrial regions of Ukraine are characterized by the increased levels of mineralization. This is further aggravated by dumping of mine waters into natural water reservoirs. Importantly, mine waters are dumped into the environment regardless of whether a mine is operational or not, which often exacerbates the situation as it is harder to control how mine waters are dumped in inactive mines. In addition, underground water and surface water in Pryazovia and in Prychornomoria; have increased levels of mineralization due to natural factors. As a result, people in many regions of Ukraine (especially the south, the east and some areas of the central and western areas) consume drinking-water with inadmissibly high levels of hardness and mineralization. The use of such water in the industry, power and municipal services, leads to increased dumps of sewage into the environment as these dumps are necessary to maintain water-circulated systems in a satisfactory condition.

The raised level of water impurity of large and small rivers of Pryazovia, other southeastern regions of Ukraine, contributes to considerable pollution of the Azov and the Black seas.

Under such conditions, development and introduction of processes for water demineralization and softening become critically important. Membrane filtration technologies of water treatment represent the most popular approach among known technologies for demineralization and softening of water. The popularity of this approach is determined by high efficiency of the processes and high quality of the purified water. With this approach, one can obtain high-quality drinking water and technological water meeting the key standards. However, wide introduction of these technological processes raises an issue of how to recycle concentrates formed at membrane filtration during water treatment. The mineralization of such concentrates exceeds $4 \mathrm{~g} / \mathrm{dm}^{3}$. Dump of such solutions in natural water reservoirs is forbidden by the current environmental legislation. Moreover, such concentrates are formed in territories where natural reservoirs are characterized by high levels of background mineralization.

The existing methods of sulphate removal from water involve using the compounds of calcium [2], barium [3], lime and aluminium coagulants [4-7]. However, using calcium compounds does not reduce the concentration of sulphates below $1500 \mathrm{mg} / \mathrm{dm}^{3}$. Using barium compounds is expensive and is accompanied by secondary pollution of water by highly toxic barium. Although removal of sulphates by sedimentation of calcium sulphate with calcium aluminate has been studied for solutions with concentration of sulphates of $400-1800 \mathrm{mg} / \mathrm{dm}^{3}$, the published works [4-7] do not consider the processes of water softening. 
Amounts of sulphates in concentrates which are formed at nanofiltration water treatment depend on the initial concentration of sulphates in natural or mine water before clearing and on the intensity of permeate intake. With permeate intake at approximately $75 \%$, the concentration of sulphates at the initial concentration of $400-1100 \mathrm{mg} / \mathrm{dm}^{3}$ in the water will result in the concentration of sulphates of $1600-4400 \mathrm{mg} / \mathrm{dm}^{3}$. In addition, resulting concentrates have high levels of hardness and alkalinity while the concentration of chlorides does not exceed $100 \mathrm{mg} / \mathrm{dm}^{3}$.

In light of these results, it is potentially expedient to process concentrates with reagent softening and removing sulphate ions. This will allow reducing the level of concentrate mineralization to permissible values. The processed concentrates can be discharged into reservoirs or can be used repeatedly in the technological process of water preparation.

The objectives of this work are to study the processes of demineralization of concentrates which appear in nanofiltration purification of mine and mineralized water with high sulphate concentration, to identify conditions to effectively soften these solutions and to remove sulphates with a complex treatment by lime and aluminium coagulants under minimal secondary pollution by chloride anions.

\section{Experimental}

Concentrates with sulphate concentration from 1200 to $4500 \mathrm{mg} / \mathrm{dm}^{3}$ at the hardness from 13 to $36 \mathrm{mg}-\mathrm{eq} / \mathrm{dm}^{3}$ were treated with lime and aluminium coagulants. We estimated the residual concentration of sulphates and chlorides, and residual hardness and alkalinity of water. As coagulants we used $2 / 3$ or $5 / 6$ aluminium hydrochloride and in some cases we used aluminium hydrochloride with sodium hydroxaluminate. The concentration of sulphates was estimated with a photometric method, while the concentration of chlorides was estimated with the method of Mora.

\section{Results and Discussion}

Efficiency of water treatment by sulphate removal, as well as the efficiency of softening, depends both on the total amounts and proportional ratio of used lime and coagulant. Under low amounts of lime increase of the dose of aluminium hydrochloride to $2 / 3$ results only in growing concentration of chlorides in water without its substantial softening and clearing from sulphates (Table 1). As the amount of lime is increased while holding the dose of coagulant fixed (Table 1), we observed an increase in the efficiency of sulphate removal. The effective softening of water is attained at the consumption of lime from 76 to $99 \mathrm{mg}$-eq $/ \mathrm{dm}^{3}$ at all doses of coagulant. Remaining alkalinity of water grows as the amount of lime used increase but it decreases as the amount of coagulant used increases.

Although $\mathrm{Al}_{2}(\mathrm{OH})_{5} \mathrm{Cl}$ is a more expensive coagulant than commonly used chloride aluminium and sulphate aluminium, $\mathrm{AlCl}_{2}(\mathrm{OH})$ and $\mathrm{Al}(\mathrm{OH})_{2} \mathrm{Cl}$, $\mathrm{Al}_{2}(\mathrm{OH})_{5} \mathrm{Cl}$ introduces fewer anions that cause secondary pollution in water.

The use of $\mathrm{Al}_{2}(\mathrm{OH})_{5} \mathrm{Cl}$ provides high efficiency of sulphate removal, and it uses smaller concentrations of chlorides in comparison with $\mathrm{Al}(\mathrm{OH})_{2} \mathrm{Cl}$ (Fig. 1). However, as a result of lower acidity of aluminium hydrochloride with high alkalinity, treated solutions still have high alkalinity, especially at low doses of coagulant.

As coagulant dose increases, the efficiency of removal of sulphates grows. However, raising lime dose above $93 \mathrm{mg}$-eq $/ \mathrm{dm}^{3}$ does not increase the efficiency of sulphate removal from a solution. Furthermore, residual concentration of sulphates can increase in some cases. The same results apply to the efficiency of softening of water (Fig. 2). Note that as coagulant dose increases, the efficiency of softening of water grows while the residual alkalinity of waters decreases. The best results for alkalinity are obtained at the maximum usage of coagulant when lime doses are at 82-108 $\mathrm{mg}$-eq $/ \mathrm{dm}^{3}$.

However, solving theproblems of purification of concentrates only at the expense of increasing the coagulant dose is not always expedient because in such a case the residual concentration of chlorides in the water increases.

Addition of anions into the water with coagulant can be prevented by using sodium hydroxaluminateas aluminium coagulant (Fig. 3).

Efficiency of water treatment from sulphates increases with using lime and aluminium coagulant by 100-150\% compared to stoichiometry-based estimates. The concentration of sulphates can reach $137-350 \mathrm{mg} / \mathrm{dm}^{3}$. However, the residual alkalinity of water grows as the usage of reagents increases. Mineralization rises with greater usage of sodium hydroxaluminate, because with the latter, sodium ions and alkali (always present in solutions as $10-20 \%$ excess) are also added into the water.

Thus, using lime and sodium hydroxaluminate can lead to high alkalinity of water. In addition, due to solubility of lime excess, water hardness is also very high. With water treatment by carbon dioxide, $\mathrm{pH}$ decreases from 12 to $7-8$. Under these conditions, calcium ions become separated as insoluble calcium carbonate. Residual hardness of water does not exceed $1 \mathrm{mg}-\mathrm{eq} / \mathrm{dm}^{3}$, although alkalinity is high. This is observed because sodium hydroxide is separated during the formation of calcium aluminate from sodium hydroxaluminate. When sodium sulphate is present in the water, sodium hydroxide also is formed at sedimentation gypsum with sodium hydroxaluminate. When water is treated with carbon dioxide, sodium hydroxide becomes soda, which explains the anomalously high water alkalinity. 
The efficiency of sulphatic ions removal from a solution $\left(\left[\mathrm{SO}_{4}^{2-}\right]=29.0 \mathrm{mg}-\mathrm{eq} / \mathrm{dm}^{3} ; \boldsymbol{H}=\mathbf{2 1 . 5} \mathrm{mg}-\mathrm{eq} / \mathrm{dm}^{3}\right.$;

$\left.\left[\mathrm{Ca}^{2+}\right]=1.8 \mathrm{mg}-\mathrm{eq} / \mathrm{dm}^{3} ;\left[\mathrm{Mg}^{2+}\right]=19.7 \mathrm{mg}-\mathrm{eq} / \mathrm{dm}^{3} ;[\mathrm{Cl}]=95 \mathrm{mg} / \mathrm{dm}^{3} ; A=19.0 \mathrm{mg}-\mathrm{eq} / \mathrm{dm}^{3}\right)$ as a function of used lime and $\mathrm{Al}(\mathrm{OH})_{2} \mathrm{Cl}$

\begin{tabular}{|c|c|c|c|c|c|c|c|c|}
\hline $\begin{array}{c}\mathrm{CaO} \text { dose, } \\
\mathrm{mg}-\mathrm{eq} / \mathrm{dm}^{3}\end{array}$ & $\begin{array}{c}\mathrm{Al}(\mathrm{OH})_{2} \mathrm{Cl}(\mathrm{by} \\
\left.\mathrm{Al}_{2} \mathrm{O}_{3}\right) \text { dose, } \\
\mathrm{mmol} / \mathrm{dm}^{3}\end{array}$ & $\mathrm{pH}$ & $\begin{array}{c}{\left[\mathrm{SO}_{4}^{2-}\right],} \\
\mathrm{mg} / \mathrm{dm}^{3}\end{array}$ & $\begin{array}{c}\text { Water hardness } \\
(H), \mathrm{mg}-\mathrm{eq} / \mathrm{dm}^{3}\end{array}$ & $\begin{array}{c}\text { Water alkalinity } \\
(A), \mathrm{mg}-\mathrm{eq} / \mathrm{dm}^{3} \\
(\mathrm{OH} ; \text { the general })\end{array}$ & $\begin{array}{c}{\left[\mathrm{Cl}^{-}\right],} \\
\mathrm{mg}^{-} \mathrm{dm}^{3}\end{array}$ & $\begin{array}{c}\text { Degree of } \\
\mathrm{SO}_{4}^{2-} \text { ions } \\
\text { removal, } \%\end{array}$ & $\begin{array}{c}\text { Degree of } \\
\text { softening }(Z), \\
\%\end{array}$ \\
\hline 47.19 & 4.5 & 7.4 & 1120 & 7.5 & $0 ; 4.4$ & 417 & 13.6 & 68.8 \\
\hline 47.19 & 6.8 & 7.5 & 600 & 18.0 & $0 ; 6.7$ & 579 & 53.7 & 25.0 \\
\hline 76.05 & 4.83 & 7.5 & 800.0 & 3.4 & $0.0 ; 9.5$ & 435 & 42.5 & 84.2 \\
\hline 87.65 & 4.83 & 7.7 & 578.0 & 2.2 & $0.0 ; 12.5$ & 447 & 58.5 & 89.8 \\
\hline 99.25 & 4.83 & 8.9 & 433.0 & 2.4 & $0.0 ; 17.0$ & 453 & 68.8 & 88.8 \\
\hline 110.85 & 4.83 & 9.7 & 480.0 & 11.7 & $4.8 ; 21.5$ & 446 & 65.5 & 45.6 \\
\hline 122.45 & 4.83 & 11.3 & 515.0 & 20.0 & $5.8 ; 34.0$ & 424 & 63.0 & 7.0 \\
\hline 134.05 & 4.83 & 11.4 & 425.0 & 27.0 & $11.0 ; 37.0$ & 419 & 69.5 & 0.0 \\
\hline 99.25 & 5.32 & 9.1 & 481.0 & 2.8 & $0.0 ; 16.5$ & 470 & 65.4 & 87.0 \\
\hline 99.25 & 5.80 & 8.7 & 330.0 & 3.0 & $0.0 ; 17.0$ & 485 & 76.3 & 86.0 \\
\hline 99.25 & 6.28 & 7.9 & 385.0 & 3.7 & $0.0 ; 11.0$ & 546 & 72.3 & 82.8 \\
\hline 99.25 & 6.77 & 7.8 & 500.0 & 4.5 & $0.0 ; 7.0$ & 551 & 64.1 & 79.1 \\
\hline 99.25 & 7.25 & 7.6 & 340.0 & 6.0 & $0.0 ; 8.5$ & 610 & 75.6 & 72.1 \\
\hline 76.05 & 7.25 & 7.9 & 476.0 & 5.0 & $0.0 ; 9.0$ & 625 & 21.0 & 76.7 \\
\hline 87.65 & 7.25 & 7.8 & 512.5 & 6.0 & $0.0 ; 9.0$ & 630 & 63.2 & 72.1 \\
\hline 99.25 & 7.25 & 7.7 & 328.5 & 8.0 & $0.0 ; 8.0$ & 627 & 76.4 & 62.8 \\
\hline 110.85 & 7.25 & 7.8 & 195.0 & 11.0 & $0.0 ; 9.0$ & 619 & 86.0 & 48.8 \\
\hline 122.45 & 7.25 & 7.9 & 130.0 & 12.0 & $0.0 ; 9.0$ & 622 & 90.7 & 44.2 \\
\hline 134.05 & 7.25 & 7.9 & 164.0 & 15.0 & $0.0 ; 10.0$ & 623 & 88.2 & 30.2 \\
\hline
\end{tabular}

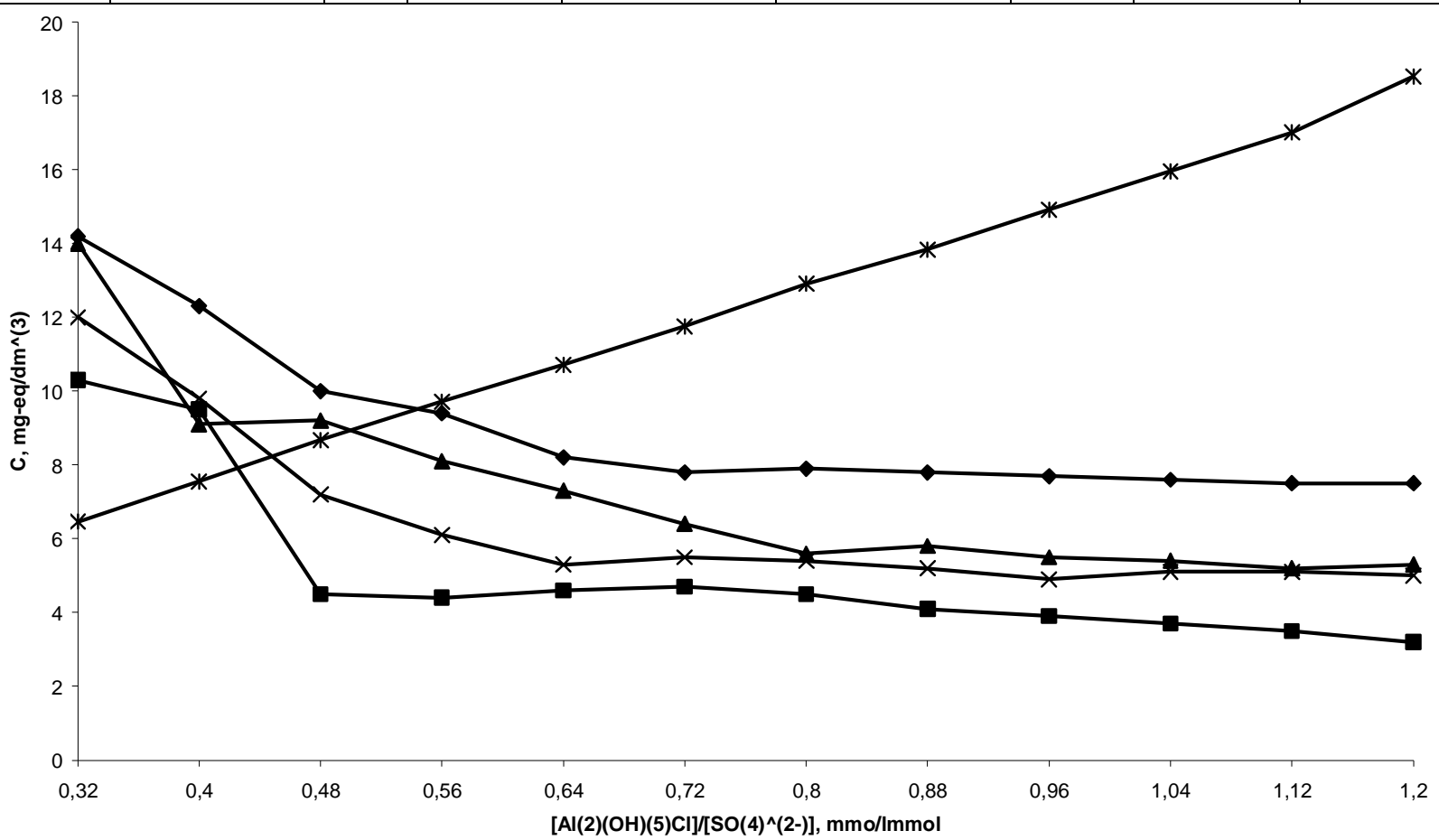

$\rightarrow-1 \rightarrow-2 \rightarrow-3 * 4 \rightarrow-5$

Fig. 1. Residual concentration of sulphates (1-4) and chlorides (5) as a function of $\mathrm{Al}_{2}(\mathrm{OH})_{5} \mathrm{Cl}$ relative to $\mathrm{SO}_{4}{ }^{2}\left(\left[\mathrm{Al}_{2}(\mathrm{OH})_{5} \mathrm{Cl}\right] /\left[\mathrm{SO}_{4}{ }^{2-}\right]\right)$

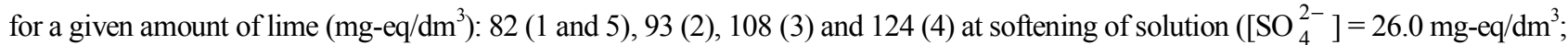
$\left.H=16.0 \mathrm{mg}-\mathrm{eq} / \mathrm{dm}^{3} ;\left[\mathrm{Ca}^{2+}\right]=1.6 \mathrm{mg}-\mathrm{eq} / \mathrm{dm}^{3} ;\left[\mathrm{Mg}^{2+}\right]=14.4 \mathrm{mg}-\mathrm{eq} / \mathrm{dm}^{3} ;[\mathrm{Cl}]=2.3 \mathrm{mg}-\mathrm{eq} / \mathrm{dm}^{3} ; A=16.0 \mathrm{mg}-\mathrm{eq} / \mathrm{dm}^{3}\right)$ 


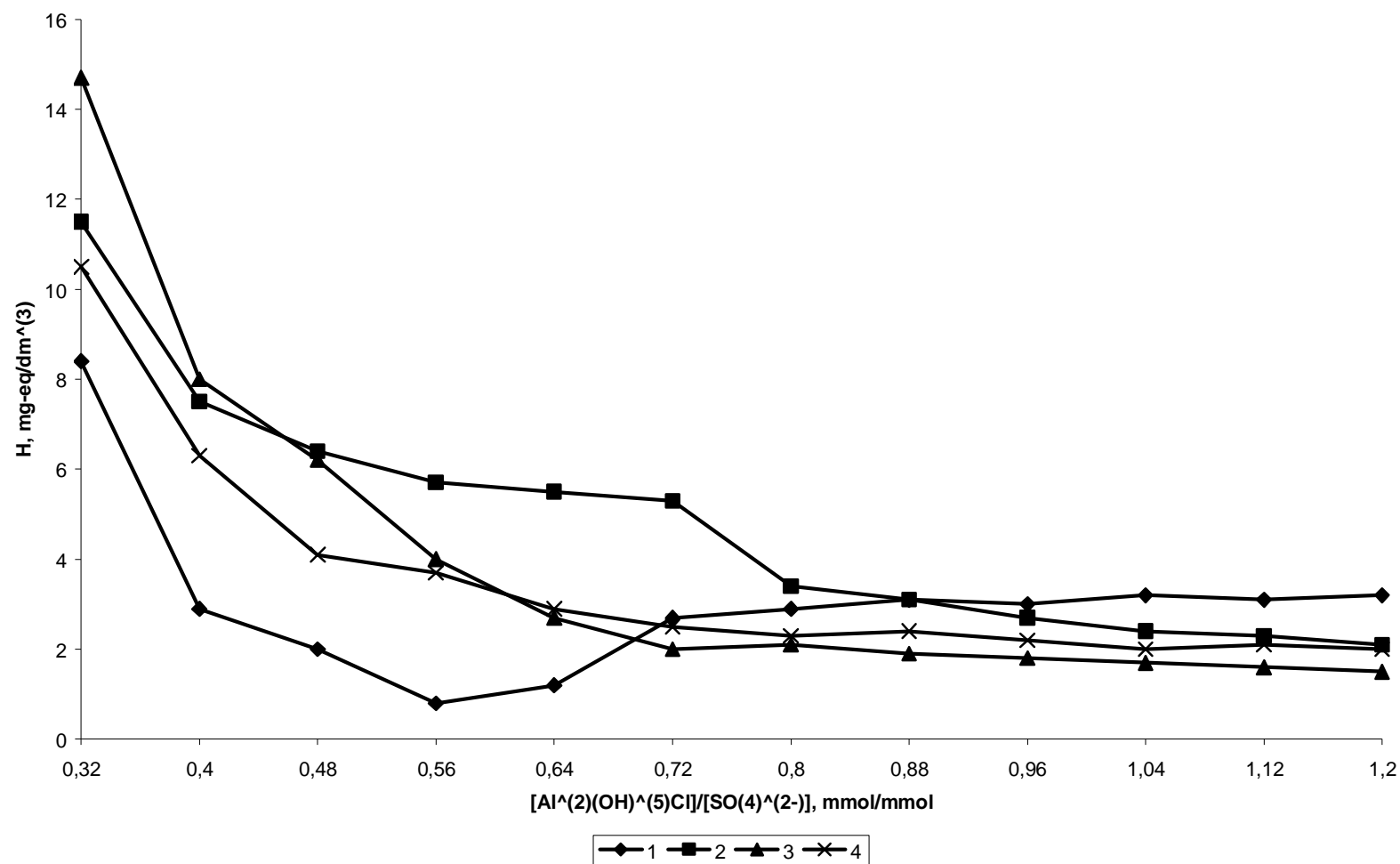

Fig. 2. Relative usage of coagulant per amount of the sulphates $\left(\left[\mathrm{Al}_{2}(\mathrm{OH})_{5} \mathrm{Cl}\right] /\left[\mathrm{SO}_{4}{ }^{2-}\right]\right)$ in the solution $\left(\left[\mathrm{SO}_{4}{ }_{4}^{2-}\right]=26.0 \mathrm{mg}\right.$-eq/ $\mathrm{dm}^{3}$; $\left.H=16.0 \mathrm{mg}-\mathrm{eq} / \mathrm{dm}^{3} ;\left[\mathrm{Ca}^{2+}\right]=1.6 \mathrm{mg}-\mathrm{eq} / \mathrm{dm}^{3} ;\left[\mathrm{Mg}^{2+}\right]=14.4 \mathrm{mg}-\mathrm{eq} / \mathrm{dm}^{3} ;[\mathrm{Cl}]=2.3 \mathrm{mg}-\mathrm{eq} / \mathrm{dm}^{3} ; A=16.0 \mathrm{mg}-\mathrm{eq} / \mathrm{dm}^{3}\right)$ as a function of residual hardness of water (1-4) at the lime dose $\left(\mathrm{mg}-\mathrm{eq} / \mathrm{dm}^{3}\right): 82$ (1), 93 (2), 108 (3) and 124 (4)

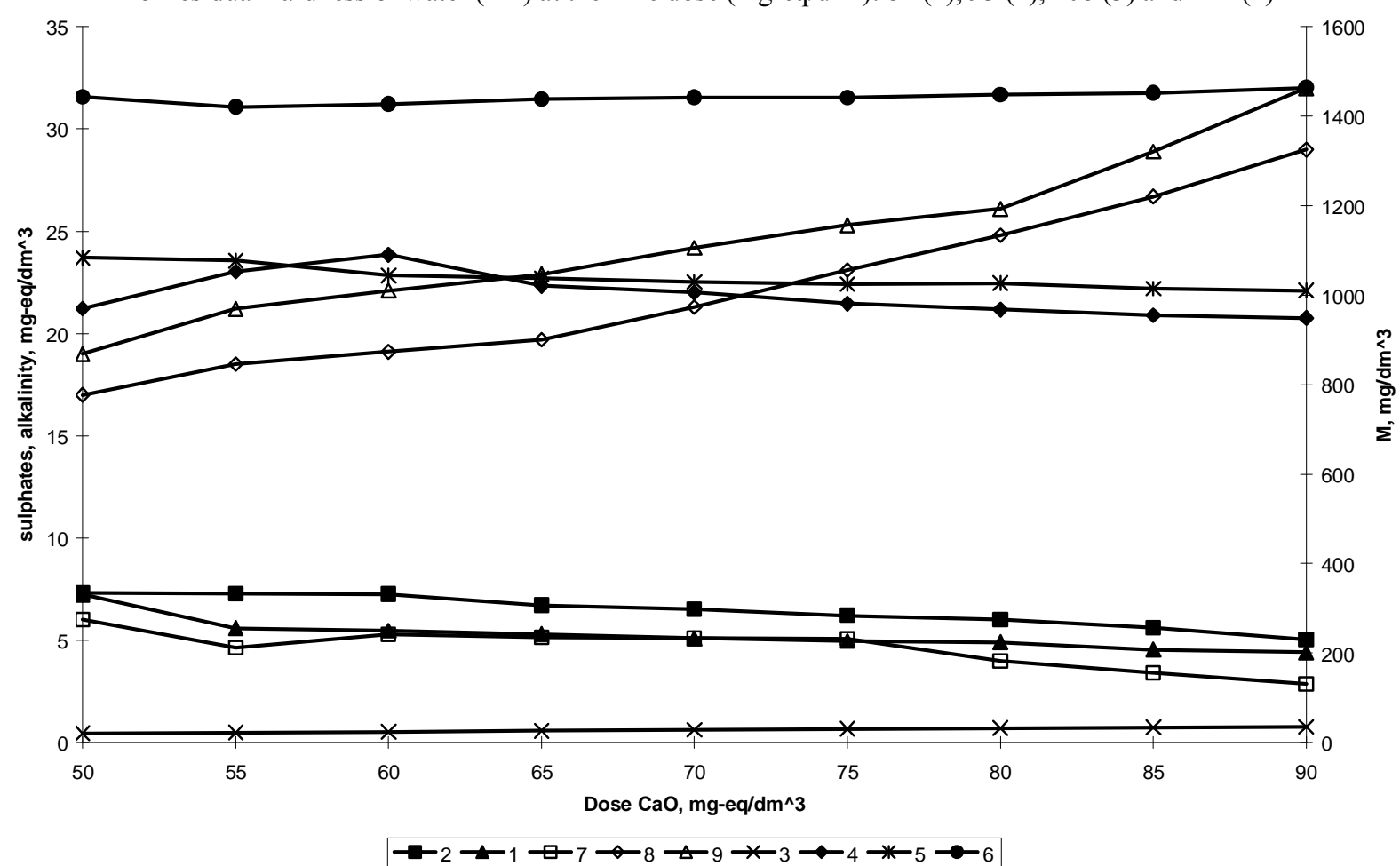

Fig. 3. Residual concentration of sulphates (1-3), alkalinity (4-6) and mineralization (7-9) as a function of lime usage at solution purification $\left(\mathrm{pH}=7.8 ;\left[\mathrm{SO}_{4}^{2-}\right]=26.2 \mathrm{mg}-\mathrm{eq} / \mathrm{dm}^{3} ; H=24.0 \mathrm{mg}-\mathrm{eq} / \mathrm{dm}^{3} ;\left[\mathrm{Ca}^{2+}\right]=7.0 \mathrm{mg}-\mathrm{eq} / \mathrm{dm}^{3} ;\left[\mathrm{Mg}^{2+}\right]=17.0 \mathrm{mg}\right.$-eq $/ \mathrm{dm}^{3} ; A=3.75 \mathrm{mg}-\mathrm{eq} / \mathrm{dm}^{3} ;$ $\left.[\mathrm{Cl}]=73 \mathrm{mg} / \mathrm{dm}^{3}\right)$ at given doses of sodium hydroxaluminate $\left(\mathrm{mg}-\mathrm{eq} / \mathrm{dm}^{3}\right): 17.5(1,4,7) ; 18.4(2,5,8) ; 21.0(3,6,9)$ 
Table 2

The effect of lime and sodium hydroxaluminate dosage on the efficiency of sulphates removal and hardness at solution treatment $\left(\left[\mathrm{SO}_{4}^{2-}\right]=65.0 \mathrm{mg}-\mathrm{eq} / \mathrm{dm}^{3} ; \mathrm{H}=36.0 \mathrm{mg}-\mathrm{eq} / \mathrm{dm}^{3} ;\left[\mathrm{Ca}^{2+}\right]=3.2 \mathrm{mg}-\mathrm{eq} / \mathrm{dm}^{3}\right.$; $\left.\left[\mathrm{Mg}^{2+}\right]=32.8 \mathrm{mg}-\mathrm{eq} / \mathrm{dm}^{3} ; A=2.9 \mathrm{mg}-\mathrm{eq} / \mathrm{dm}^{3}\right)$ by lime, sodium hydroxaluminate and carbon dioxide

\begin{tabular}{|c|c|c|c|c|c|c|c|}
\hline \multirow{2}{*}{$\begin{array}{l}\mathrm{CaO} \text { dose, } \\
\mathrm{mg} \text {-eq } / \mathrm{dm}^{3}\end{array}$} & \multirow{2}{*}{$\begin{array}{c}\mathrm{NaAl}(\mathrm{OH})_{4} \\
\left.\text { (by } \mathrm{Al}_{2} \mathrm{O}_{3}\right) \text { dose } \\
\mathrm{mmol} / \mathrm{dm}^{3}\end{array}$} & \multicolumn{2}{|c|}{$\mathrm{SO}_{4}^{2-}$} & \multirow{2}{*}{$\begin{array}{c}H^{*} \\
\mathrm{mg-} \\
\mathrm{eq} / \mathrm{dm}^{3}\end{array}$} & \multirow{2}{*}{$\begin{array}{c}A, \mathrm{mg}-\mathrm{eq} / \mathrm{dm}^{3} \\
\left(\mathrm{OH}^{-} ; \text {the }\right. \\
\text { general })\end{array}$} & \multirow{2}{*}{$\begin{array}{l}\text { Degree of } \\
\mathrm{SO}_{4}^{2-} \text { ions } \\
\text { removal, \% }\end{array}$} & \multirow{2}{*}{$\begin{array}{c}\text { Degree of } \\
\text { softening } \\
(Z), \%\end{array}$} \\
\hline & & mg-eq $/ \mathrm{dm}^{3}$ & $\mathrm{mg} / \mathrm{dm}^{3}$ & & & & \\
\hline 166 & 10.83 & 14.4 & 690 & 5.7 & $0.0 ; 46.0$ & 77.8 & 84.2 \\
\hline 166 & 13.00 & 13.3 & 640 & 5.2 & $0.0 ; 57.0$ & 79.5 & 85.6 \\
\hline 166 & 16.25 & 8.4 & 405 & 3.0 & $0.0 ; 63.5$ & 87.1 & 91.7 \\
\hline 192 & 10.83 & 10.8 & 518 & 3.0 & $0.0 ; 47.5$ & 83.4 & 91.7 \\
\hline 231 & 10.83 & 8.7 & 418 & 9.0 & $0.0 ; 60.5$ & 86.6 & 75.0 \\
\hline 231 & 13.00 & 8.9 & 427 & 3.2 & $0.0 ; 49.0$ & 86.3 & 91.1 \\
\hline 231 & 16.25 & 8.2 & 395 & 2.9 & $0.0 ; 61.0$ & 87.4 & 91.9 \\
\hline 130 & 10.83 & 15.6 & 749 & 6.3 & $0.0 ; 27.1$ & 76.0 & 82.5 \\
\hline 156 & 10.83 & 14.7 & 706 & 4.9 & $0.0 ; 31.2$ & 77.4 & 86.4 \\
\hline 195 & 10.83 & 7.8 & 374 & 5.1 & $0.0 ; 34.6$ & 88.0 & 85.8 \\
\hline 221 & 10.83 & 6.4 & 307 & 7.6 & $0.0 ; 38.5$ & 90.2 & 78.9 \\
\hline
\end{tabular}

Note: * hardness defined before the treatment of water by $\mathrm{CO}_{2}$

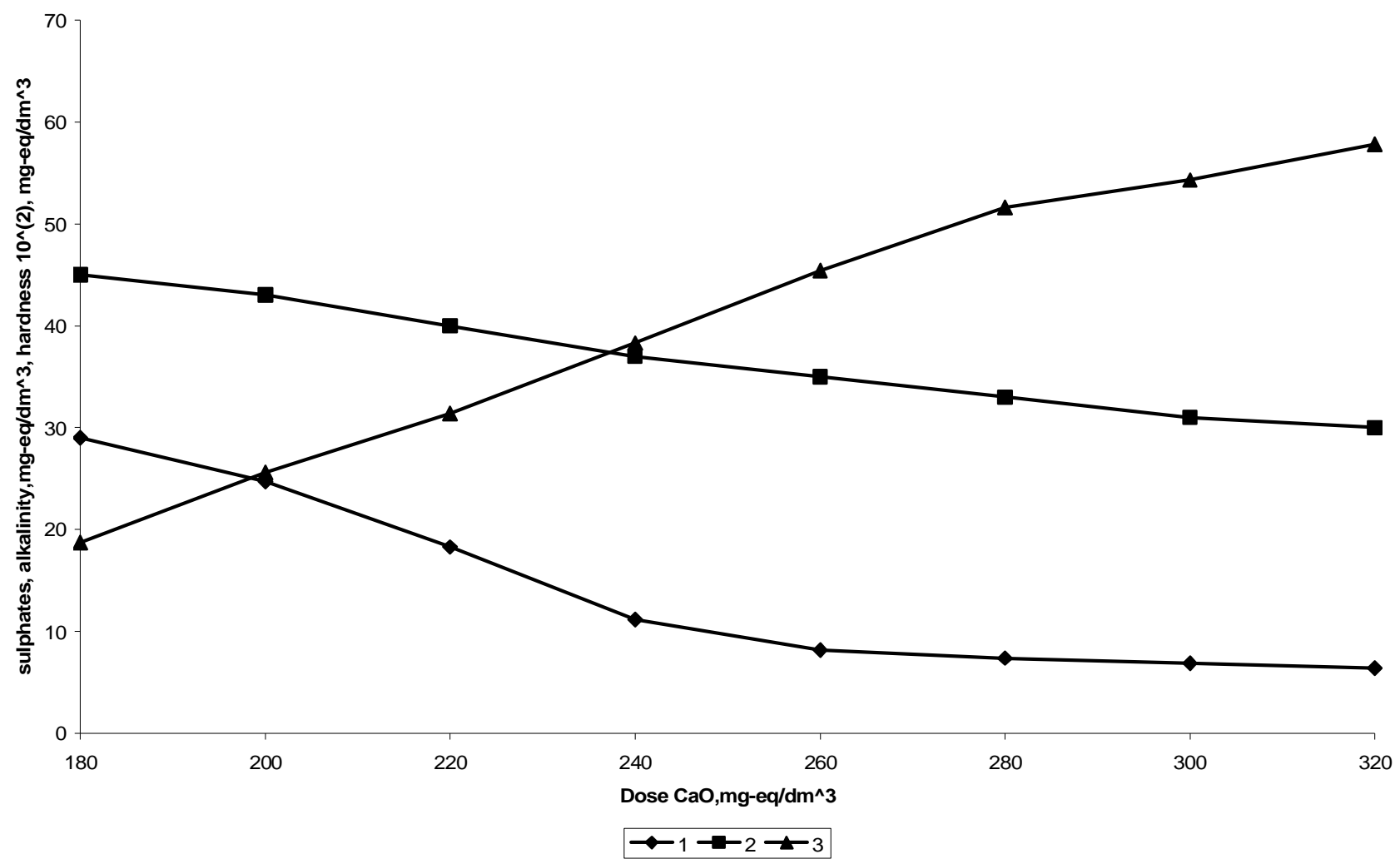

Fig. 4. The effect of lime usage at the dose of sodium hydroxaluminate of $15.6 \mathrm{mg}-\mathrm{eq} / \mathrm{dm}^{3}$ on residual concentration of sulphates (1), hardness (2), alkalinity (3) solutions $\left(\left[\mathrm{SO}_{4}^{2-}\right]=93.8 \mathrm{mg}-\mathrm{eq} / \mathrm{dm}^{3} ; H=14.6 \mathrm{mg}-\mathrm{eq} / \mathrm{dm}^{3} ;\left[\mathrm{Ca}^{2+}\right]=1.6 \mathrm{mg}-\mathrm{eq} / \mathrm{dm}^{3}\right.$;

$\left[\mathrm{Mg}^{2+}\right]=13.0 \mathrm{mg}-\mathrm{eq} / \mathrm{dm}^{3} ; A=5.0 \mathrm{mg}$-eq $/ \mathrm{dm}^{3}$ ) 
The influence of dose of lime, sodium hydroxaluminate and 5/6 aluminium hydrochloride on efficiency of demineralization of solution ([SO $\left.{ }_{4}^{2-}\right]=26.2 \mathrm{mg}-\mathrm{eq} / \mathrm{dm}^{3} ; \mathrm{H}=24.0 \mathrm{mg}-\mathrm{eq} / \mathrm{dm}^{3} ;[\mathrm{Cl}]=73 \mathrm{mg} / \mathrm{dm}^{3}$; $A=3.75 \mathrm{mg}-\mathrm{eq} / \mathrm{dm}^{3}$; a mineralization $2200 \mathrm{mg} / \mathrm{dm}^{3}$ )

\begin{tabular}{|c|c|c|c|c|c|c|c|c|}
\hline \multicolumn{3}{|c|}{$\begin{array}{c}\text { Dose, } \\
\mathrm{mmol} / \mathrm{dm}^{3}\end{array}$} & \multicolumn{2}{|c|}{$\mathrm{SO}_{4}^{2-}$} & \multirow{2}{*}{$\begin{array}{l}H, \mathrm{mg}_{-} \\
\mathrm{eq} / \mathrm{dm}^{3}\end{array}$} & \multirow{2}{*}{$\begin{array}{l}A, \mathrm{mg}^{-} \\
\mathrm{eq} / \mathrm{dm}^{3}\end{array}$} & \multirow[t]{2}{*}{$M, \mathrm{mg} / \mathrm{dm}^{3}$} & \multirow{2}{*}{$\begin{array}{c}\text { Degree of } \\
\text { softening }(Z), \\
\%\end{array}$} \\
\hline $\mathrm{CaO}$ & $\mathrm{NaAl}(\mathrm{OH})_{4}$ & $\mathrm{Al}_{2}(\mathrm{OH})_{5} \mathrm{Cl}$ & mg-eq $/ \mathrm{dm}^{3}$ & $\mathrm{mg} / \mathrm{dm}^{3}$ & & & & \\
\hline 52.40 & 5.83 & 5.83 & 7.30 & 350 & 4.32 & 3.00 & 860 & 82 \\
\hline 62.88 & 5.83 & 5.83 & 7.26 & 348 & 5.41 & 4.11 & 857 & 77.5 \\
\hline 78.60 & 5.83 & 5.83 & 6.02 & 288 & 9.42 & 8.31 & 859 & 60.8 \\
\hline 89.08 & 5.83 & 5.83 & 5.04 & 242 & 10.94 & 10.52 & 851 & 54.4 \\
\hline 52.40 & 6.13 & 6.13 & 7.23 & 347 & 4.15 & 4.22 & 929 & 82.7 \\
\hline 55.02 & 6.13 & 6.13 & 5.73 & 275 & 4.11 & 4.87 & 937 & 82.9 \\
\hline 57.64 & 6.13 & 6.13 & 5.60 & 269 & 4.84 & 6.93 & 925 & 79.8 \\
\hline 62.88 & 6.13 & 6.13 & 5.47 & 263 & 5.12 & 7.84 & 927 & 78.7 \\
\hline 78.60 & 6.13 & 6.13 & 4.90 & 235 & 8.13 & 9.15 & 947 & 66.1 \\
\hline 89.08 & 6.13 & 6.13 & 4.40 & 211 & 9.18 & 10.31 & 965 & 61.8 \\
\hline 52.40 & 7.00 & 7.00 & 6.00 & 288 & 3.21 & 3.01 & 968 & 86.6 \\
\hline 55.02 & 7.00 & 7.00 & 4.64 & 223 & 3.85 & 4.07 & 957 & 84.0 \\
\hline 57.64 & 7.00 & 7.00 & 5.30 & 254 & 4.07 & 6.73 & 963 & 83.0 \\
\hline 62.88 & 7.00 & 7.00 & 5.10 & 245 & 4.49 & 6.64 & 948 & 81.3 \\
\hline 78.60 & 7.00 & 7.00 & 3.20 & 154 & 6.44 & 8.96 & 971 & 73.2 \\
\hline 89.09 & 7.00 & 7.00 & 2.85 & 137 & 8.85 & 10.12 & 1009 & 63.1 \\
\hline
\end{tabular}

The formation of alkali with sedimentation of calcium sulphoaluminate during lime and aluminum coagulant water treatment can be described with the equations:

$$
\begin{gathered}
3 \mathrm{Na}_{2} \mathrm{SO}_{4}+2 \mathrm{NaAl}(\mathrm{OH})_{4}+6 \mathrm{Ca}(\mathrm{OH})_{2}+25 \mathrm{H}_{2} \mathrm{O} \leftrightarrow \\
\leftrightarrow 3 \mathrm{CaO} \cdot \mathrm{Al}_{2} \mathrm{O}_{3} \cdot 3 \mathrm{CaSO} \mathrm{CO}_{4} \cdot 31 \mathrm{H}_{2} \mathrm{O} \downarrow+8 \mathrm{NaOH} \\
3 \mathrm{Na}_{2} \mathrm{SO}_{4}+2 \mathrm{Al}(\mathrm{OH})_{2} \mathrm{Cl}+6 \mathrm{Ca}(\mathrm{OH})_{2}+25 \mathrm{H}_{2} \mathrm{O} \leftrightarrow \\
\leftrightarrow 3 \mathrm{CaO}^{2} \cdot \mathrm{Al}_{2} \mathrm{O}_{3} \cdot 3 \mathrm{CaSO} \mathrm{SO}_{4} \cdot 31 \mathrm{H}_{2} \mathrm{O} \downarrow+2 \mathrm{NaCl}+4 \mathrm{NaOH} \\
3 \mathrm{Na}_{2} \mathrm{SO}_{4}+\mathrm{Al}_{2}(\mathrm{OH})_{5} \mathrm{Cl}+6 \mathrm{Ca}(\mathrm{OH})_{2}+25 \mathrm{H}_{2} \mathrm{O} \leftrightarrow \\
\leftrightarrow 3 \mathrm{CaO} \cdot \mathrm{Al}_{2} \mathrm{O}_{3} \cdot 3 \mathrm{CaSO}_{4} \cdot 31 \mathrm{H}_{2} \mathrm{O} \downarrow+\mathrm{NaCl}+5 \mathrm{NaOH}
\end{gathered}
$$

When sulphates of calcium and magnesium are present, alkali is formed only if sodium hydroxaluminate is used:

$3 \mathrm{MgSO}_{4}+2 \mathrm{NaAl}(\mathrm{OH})_{4}+6 \mathrm{Ca}(\mathrm{OH})_{2}+25 \mathrm{H}_{2} \mathrm{O} \leftrightarrow$ $\leftrightarrow 3 \mathrm{CaO} \cdot \mathrm{Al}_{2} \mathrm{O}_{3} \cdot 3 \mathrm{CaSO}_{4} \cdot 31 \mathrm{H}_{2} \mathrm{O} \downarrow+2 \mathrm{NaOH}+3 \mathrm{Mg}(\mathrm{OH})_{2} \downarrow(4)$

$$
\begin{aligned}
& 3 \mathrm{CaSO}_{4}+2 \mathrm{NaAl}(\mathrm{OH})_{4}+3 \mathrm{Ca}(\mathrm{OH})_{2}+25 \mathrm{H}_{2} \mathrm{O} \leftrightarrow \\
& \leftrightarrow 3 \mathrm{CaO} \cdot \mathrm{Al}_{2} \mathrm{O}_{3} \cdot 3 \mathrm{CaSO}_{4} \cdot 31 \mathrm{H}_{2} \mathrm{O} \downarrow+2 \mathrm{NaOH}
\end{aligned}
$$

Composition of calcium sulphoaluminate sediment was measured according to data available in the literature [7].

The efficiency of sulphate removal was high at considerable concentration of sulphates, including sodium sulphate, in the water (Table 2, Fig. 4). However, alkalinity of solutions was high even after the water was treated with carbon dioxide because of high doses of sodium hydroxaluminate and high concentration of sodium sulphate in the water.
The best results were obtained by using sodium hydroxaluminate and 5/6 aluminium hydroxchloride in equimolar ratio (Table 3 ).

In this case, solutions were not treated with carbon dioxide after treatment with lime and aluminium coagulant. The treatment was shortened at least to 2 stages (sparging and filtering). During this procedure, we observed the neutralization of alkali formed at the hydrolysis of sodium hydroxaluminate by hydrochloric acid produced in the hydrolysis of aluminium hydrochloride. We found that in addition to sulphate removal, general mineralization decreased from about $2200 \mathrm{mg} / \mathrm{dm}^{3}$ to less than $1000 \mathrm{mg} / \mathrm{dm}^{3}$. Softening of water was effective, too. Softening efficiency increased as the usage of line increased. Alkalinity was also within the permitted levels.

\section{Conclusions}

We established how the usage and relative amounts of lime and 5/6 aluminium hydrochloride affect the effectiveness of sulphate removal from water and the efficiency of water softening. We showed that the efficiency of water treatment growswith increasing dose of coagulant when lime is used in stoichiometric quantities and with lime excess up to $50 \%$. 
We established the relationship between the initial concentration of sulphates in water, water hardness, alkalinity, and both total and relative amounts of limeand coagulant. This allowed us to identify the conditions of the effective water treatment from sulphates at permissible concentration of chlorides in water.

We found that by using lime, sodium hydroxaluminate and carbonic gas, one can achieve effective water treatment from sulphates and effective softening of water at high values of alkalinity of water. The effectiveness of these treatments depends on the overall concentration of sulphates, the amount of used sodium hydroxaluminate, and concentration of sodium sulphate in water.

We showed that by combined usage of $5 / 6$ aluminium hydrochloride and sodium hydroxaluminate in water liming one can achieve high degree of water softening and deep purification from sulphates with reduced residual concentration of chlorides in water.

\section{References}

[1] Belichenko Y.: Zamknytue Systemy Vodoobespecheniya Khimicheskih Proizvodstv. Khimiya, Moskwa 1990.
[2] Lebedev V., Lokshin E. and Barmin I.: Obogashchenie Ryd, 2007, 3, 42.

[3] Kubasov V. and Chinkin V.: Tsvetnaya Metallyrgiya, 2010, 3, 26.

[4] Berengarten M., Baranov D. and Vorobyeva T.: Voda: Khimiya i Ekol., 2008, 1, 13.

[5] Butseva L. and Potapova L.: Ochistka Prirodnykh i Stochnykh Vod. Sbornik. NIIVODGEO, Moskwa 2009.

[6] Salnikova E., Gofenberg I., Turanina E., etc.: Khimiya i Techn. Vody, 1992, 14, 152.

[7] Salnikova E. and Peredery O.: Tsvetnye Metaly, 1983, 12, 22.

\section{ЗАСТОСУВАННЯ АЛЮМІНІЕВИХ КОАГУЛЯНТІВ ДЛЯ ВИДАЛЕННЯ СУЛЬФАТІВ ІЗ ШАХТНИХ ВОД}

\footnotetext{
Анотація. Представлені результати із очищення розчинів, щуо містять сульфати у високих концентраціях $i$ характеризуються високою жорсткістю. Показано, що суттєвого зниження вторинного забруднення хлоридами досягнуто при комплексному використанні як коагулянти гідроксохлориду алюмінію $і$ алюмінату натрію. Встановлено, що підвищити ефективність очищення води від сульфатів та іï пом'якшення можна при обробленніі води вуглекислим газом.

Ключові слова: нанофільтраційне очщщення води, сульфати, жорсткість води, пом'якшення, алюмінієві коагулянти, вапно, шахтні води.
} 